\title{
Multivariate and statistical approaches for the evaluation of heavy metals pollution at e-waste dumping sites
}

\author{
Pankaj Kumar $^{1}$ D M. H. Fulekar ${ }^{1}$
}

Received: 1 July 2019 / Accepted: 22 October 2019 / Published online: 29 October 2019

(c) Springer Nature Switzerland AG 2019

\begin{abstract}
Electronic waste pollution is a growing concern due to its hazardous effects on the environment and human health. Among many contaminants from e-waste, excessive levels of heavy metals in soil, which are far beyond the permissible limit, have led to many research studies at e-waste dumping sites majorly in the developing nations like India and China. The present study was conducted to assess the effect of e-waste dumping on the soil profile; therefore, the soil quality was analyzed for various physicochemical and heavy metals characteristics. The concentration of heavy metals in the soil samples was determined using inductively coupled plasma optical emission spectrometer. Soil samples were found to contain a higher amount of different heavy metals like copper, zinc, nickel, lead, manganese, chromium, cadmium, and iron. Correlation and principal component analysis were performed to establish a better insight into the degradation of soil quality. The contamination factor and pollution load index were evaluated statistically to assess the heavy metal pollution. The significant difference among the soil quality parameters inferred the hazardous impact of e-waste on the soil profile, and the pollution load index indicated that the sites are highly polluted with heavy metals. The present study contributes to a deeper understanding of the heavy metal contamination at e-waste dumping sites.
\end{abstract}

Keywords E-waste $\cdot$ Heavy metals · Principal component analysis $\cdot$ Contamination factor $\cdot$ Cluster analysis · Pollution load index

\section{Introduction}

With the rapid development in the information technology sector and fast-paced innovations in the electrical and electronics industry [36,50], large quantities of electronic equipments are being discarded globally [77]. E-waste is one of the fastest growing sources of waste and now represents an emergent environmental concern [45].

Waste electronic equipments constitute over $5 \%$ of urban waste in developed countries and every year approximately $20-50$ million tons of e-waste is produced globally and it is anticipated to increase $3-5 \%$ annually $[22,48]$. The lethal impacts of recycling and discarding of e-waste on soil ecosystems have been reported in many countries $[29,71,72]$. The rapid growth of e-waste has led to inappropriate management techniques in both developed and developing countries, resulting in multi-dimensional influences on the environment $[52,71]$.

Several research studies have revealed the significant influences of heavy metal pollution on the environment and human health $[18,21,50]$. E-waste is considered more hazardous than any other waste as it contains a huge variety of toxic elements, namely $\mathrm{Pb}, \mathrm{Cd}, \mathrm{Cr}, \mathrm{Hg}, \mathrm{PVC}, \mathrm{BFRs}$, beryllium, antimony, and phthalates. Long-term exposure to these materials can harm the sensory systems, kidney, bones, reproductive, and endocrine system [25].

Currently, heavy metals contamination has become one of the most hazardous environmental challenges due

Pankaj Kumar, pankajb434@yahoo.com | 'School of Environment and Sustainable Development, Central University of Gujarat, Gandhinagar, Gujarat 382030, India. 
to their tendency for bioaccumulation and toxic effects on plants, animals, and human beings $[8,31,37,57]$. The industrial activities, including mining, metallurgy, petroleum-producing, machine manufacturing, and metal finishing, affect the environment directly or indirectly [34]. The main concern is the discharge and accumulation of heavy metals into the soil, as metals are not degradable and largely affect the ecosystem. Most of the heavy metals are extremely toxic even at low concentrations. $\mathrm{Cd}, \mathrm{Cr}, \mathrm{Pb}$, $\mathrm{Hg}, \mathrm{As}, \mathrm{Ni}, \mathrm{Zn}, \mathrm{Cu}$, and $\mathrm{Ag}$ are not only poisonous but are even carcinogenic [53].

The principal objective of this study was to determine the origin, dispersal, and evaluation of the environmental risk associated with heavy metals contamination. The objective was attained, using various multivariate and statistical approaches including the soil physicochemical properties, nutrient status, and heavy metals distribution at the selected e-waste dumping sites. Despite the fact that numerous reports are available on heavy metal contaminations, an inclusive study correlating various parameters statistically to soil quality in the selected regions is largely unassessed.

\section{Materials and methods}

\subsection{Site description}

Ahmedabad, the largest industrial hub in Gujarat with a phenomenal growth record, has been an important base of trades and industries. Ahmedabad lies at $23.03^{\circ} \mathrm{N}$ $72.58^{\circ} \mathrm{E}$ in western parts of India at 53 meters above sea level in north-central Gujarat, which covers an area of $464 \mathrm{~km}^{2}$. The climatic conditions are mostly semi-arid due to the closeness with the Arabian Sea. According to the Bureau of Indian Standards, the city comes under seismic zone 3. Typically, the climate stays dry, except during monsoon season. The present research study was carried out at three different e-waste dumping sites, which were close to Ahmedabad railway station. Five samples were obtained from each selected study site and the locations of sampling sites are shown in Fig. 1 with coordination given.

\subsection{Sampling procedure and analytical methodology}

Soil samples were collected from the depth of $(15-30 \mathrm{~cm})$ and immediately transferred to an airtight container. The soil samples then transported to the laboratory and samples were prepared to analyze the physicochemical and heavy metals properties. $\mathrm{pH}$ was estimated $(1: 2.5 \mathrm{w} / \mathrm{v})$ by digital $\mathrm{pH}$ meter [70]. Electrical conductivity was determined $(1: 2.5 \mathrm{w} / \mathrm{v})$ by conductivity meter. Organic carbon and organic matter were estimated as per the method recommended by Osuji and Adesiyan [46]. Sulfate was estimated by the turbidimetric method [13], available phosphorus was determined according to Kovar et al. [24], and nitrate was assessed according to Cataldo et al. [9]. Similarly, soil moisture content, water holding capacity, alkalinity, and potassium concentrations were analyzed as per the standard methods.

\subsection{Heavy metals analysis in e-waste contaminated samples}

Soil samples were prepared for heavy metal quantification using the method suggested by the State Environmental Protection Administration [31]. Air-dried and sieved samples were digested with $\mathrm{HCl}-\mathrm{HNO}_{3}-\mathrm{HF}-\mathrm{HClO}_{4}$ solution for the analysis of $\mathrm{Pb}, \mathrm{Zn}, \mathrm{Cd}, \mathrm{Cu}, \mathrm{Mn}, \mathrm{Fe}$, and $\mathrm{Ni}$ [14], and for the analysis of $\mathrm{Cr}$, the samples were digested with $\mathrm{HNO}_{3}-\mathrm{HClO}_{4}-\mathrm{HF}$ solution $[20,78]$. The obtained solution was heated for $4-6 \mathrm{~h}$ at $120^{\circ} \mathrm{C}$ on hot plate and filtered using Whatman filter paper no. 42. The filtrate was then diluted with distilled water till the total volume reached to $20 \mathrm{ml}$. The concentrations of $\mathrm{Cr}, \mathrm{Pb}, \mathrm{Cd}, \mathrm{Fe}, \mathrm{Cu}, \mathrm{Ni}, \mathrm{Mn}$, and $\mathrm{Zn}$ were calculated using Perkin Elmer Optima 7300 DV ICP-OES. The samples were analyzed in triplicate, and the concentration of the metals was reported in $\mathrm{mg} / \mathrm{kg}$.

\subsection{Multivariate and statistical analysis}

The data obtained through the laboratory experiments (physicochemical and heavy metals concentration) were analyzed, tabulated into tables, and shown in the form of Mean \pm SD. Principal component and cluster analysis, the most suitable multivariate approaches for environmentalbased research studies [38], were performed to analyze the acquired data. Principal component analysis (PCA) bi-plot: standardized PC1 and PC2 scores were plotted to decrease the data and to extract a lesser number of independent factors for analyzing relations among experimental variables [79], starts with the correlation matrix defining the distribution of the original variables and extracting the eigenvalues and eigenvectors [5]. PCA and Pearson correlation used to determine the relationship among the soil characteristics at each sampling point and to explore the homology of soil contamination. Correlation and principal component were executed by Origin software. Cluster analysis was instigated to find out the similarity index among all the sampling points of e-waste sites, based on their physicochemical and heavy metals properties using Bray-Curtis cluster analysis (Single Link) by Biodiversity Professional software. Cluster analysis classifies the 


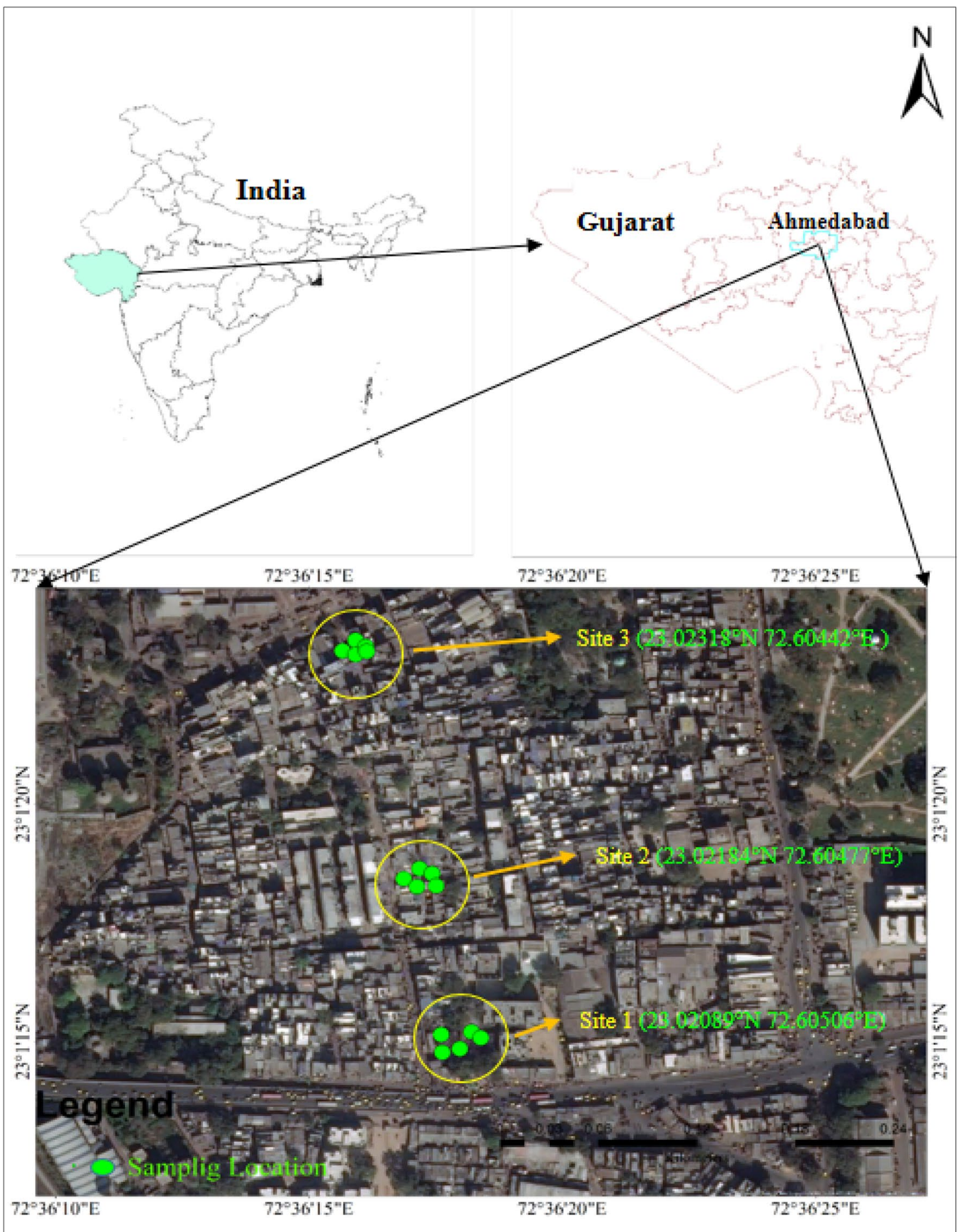

Fig. 1 Study area

contamination status and possible sources of heavy metal pollution in the study area $[32,49,73,74]$. A Dendrogram is commonly used for summarizing classified clustering.

\subsection{Contamination factor and degree of contamination}

The contamination factor is the ratio of the concentration of metal $\left(C_{M}\right)$ to the background values $\left(C_{B}\right)$. Contamination 
degree $\left(C_{\text {deg }}\right)$ is the sum of contamination factors for all the elements. Hakanson [17] suggested four classes of contamination factor and contamination degree. $\mathrm{CFs}<1$ refers to low contamination factor; $1 \leq \mathrm{CFs}<3$ means moderate contamination factor; $3 \leq \mathrm{CFs}<6$ indicates considerable contamination factor and $C F s \geq 6$ indicates very high contamination factor; and $C_{\text {deg }}<8$ refers to low contamination degree; $8 \leq C_{\mathrm{deg}}<16$ means moderate contamination degree; $16 \leq C_{\mathrm{deg}}<32$ indicates considerable contamination degree; and $32 \leq C_{\text {deg }}$ refers to very high degree of contamination.

$C f=\frac{C_{M}}{C_{B}}$

where $C_{M}$ is the measured concentration in the soil for the metal, and $C_{B}$ is the background value for the metal.

\subsection{Pollution load index}

An integrated pollution load index of metals is calculated to assess the soil quality $[31,62]$. The PLI determined as the $n$th root of the product of the $n$ CF:

$\mathrm{PLI}=\sqrt[n]{C F 1 \times C F 2 \times C F 3 \times C F 4 \times \cdots \times C F n}$

where $n$ is the total number of metals analyzed, the PLI values higher than 1 implies metal pollution, otherwise $(\mathrm{PLI}<1)$, there is no metal pollution [55].

\subsection{Geoaccumulation index $\left(I_{\text {geo }}\right)$}

The geoaccumulation index $\left(I_{\text {geo }}\right)$ commonly evaluates the pollution by comparing the obtained heavy metals concentration to background concentration. It is calculated by the equation

$I_{\text {geo }}=\log _{2}\left[C_{n} / 1.5 * B_{n}\right]$

where $C_{n}$ is the obtained concentration for the metal $n$, and $B_{n}$ is the background value for the metal $n$ in the soil [66], and the factor 1.5 used due to the possible variations in the background data. Müller [43] has reported six classes of $I_{\text {geo }}$ (Table 1). Class 6 is an open class and includes all values of the geoaccumulation index greater than class 5.

\section{Results and discussion}

\subsection{Physicochemical characterization of contaminated soil}

The physicochemical properties of the contaminated soil samples were highly diversified in nature (Table 2). The
Table 1 Classes of the geoaccumulation Index $\left(I_{\text {geo }}\right)$

\begin{tabular}{lll}
\hline Class & Value & Soil quality \\
\hline 0 & $I_{\text {geo }} \leq 0$ & Practically uncontaminated \\
1 & $0<I_{\text {geo }}<1$ & Uncontaminated to moderately contaminated \\
2 & $1<I_{\text {geo }}<2$ & Moderately contaminated \\
3 & $2<I_{\text {geo }}<3$ & Moderately to heavily contaminated \\
4 & $3<I_{\text {geo }}<4$ & Heavily contaminated \\
5 & $4<I_{\text {geo }}<5$ & Heavily to extremely contaminated \\
6 & $5<I_{\text {geo }}$ & Extremely contaminated \\
\hline
\end{tabular}

significance level among the three different sampling sites could be attributed to the composition of e-wastes, structure of the soil, e-waste disposal methods, and management techniques.

The soil samples belong to fine to very fine sandy soil, having a distinctive smell with unnatural colors. The variations in the color might be due to the higher quantity of organic matter and metals composition of the soil [68].

The temperature of the dumping sites was observed $21.64 \pm 0.94{ }^{\circ} \mathrm{C}$ for site $1,21.99 \pm 1.06{ }^{\circ} \mathrm{C}$ for site 2 and $26 \pm 1.21{ }^{\circ} \mathrm{C}$ for site 3 . The soil temperature is the most significant property, which affects the various biological activities and regulates the nutrient conversion in the soil $[61,76]$. The $\mathrm{pH}$ of the polluted sites perceived slightly basic, which suggested that the dumping sites were marginally alkaline and predominantly related to the metabolite's accretion and the availability of nutrients in the soil [54]. Electrical conductivity was found highest at site 2 followed by site 1 and site 3 . The electrical conductivity of soil influenced by the presence of metallic scraps which are the main components of the dumping sites and specified the quality of the soil and offered a suitable way to estimate the whole quantity of ionizable salts in the soil $[4,23,41]$. Similar results were reported by Uba et al. [67] at waste dumping sites at Zaira, Nigeria.

The soil moisture was found to be higher in site 3 as compared to site 1 and site 2 . Several physicochemical properties including $\mathrm{pH}$ and nitrogen of the soil are mainly reliant on the higher soil moisture [35]. The organic carbon ranged from $1.55 \pm 0.06 \%, 1.47 \pm 0.8$, and $1.32 \pm 0.09$ at the three sites, respectively, which specified the burning of various organic and inorganic compounds found in e-waste [2]. The organic matter found more in sites 1 followed by site 3 and site 2 . The organic matter (>2.0\%) in soils is favorable for metal chelation [65] and decreases the mobility of metals in soil $[10,11,21]$. The quantity of organic matter at the selected dumping sites was significantly higher due to the variety of disposed waste materials. Similar results were found by Uba et al. [67] at the dumping sites of Zaria Metropolis, Nigeria. The current findings also supported by Oyedele et al. [47], described 
Table 2 Physicochemical characterization of soil from different sampling sites

\begin{tabular}{llll}
\hline Parameters & $\begin{array}{l}\text { Site 1 } \\
\text { Mean } \pm \text { SD }\end{array}$ & $\begin{array}{l}\text { Site 2 } \\
\text { Mean } \pm \text { SD }\end{array}$ & $\begin{array}{l}\text { Site 3 } \\
\text { Mean } \pm \text { SD }\end{array}$ \\
\hline Color & Dark brown & Brown & Black \\
Texture & Sandy-loamy & Sandy-loamy & Sandy-loamy \\
Temperature $\left({ }^{\circ} \mathrm{C}\right)$ & $21.64 \pm 0.94$ & $21.99 \pm 1.06$ & $26.36 \pm 1.21$ \\
$\mathrm{pH}$ & $7.22 \pm 0.04$ & $7.44 \pm 0.26$ & $7.72 \pm 0.17$ \\
EC $(\mathrm{ms} / \mathrm{cm})$ & $2.30 \pm 0.13$ & $4.16 \pm 0.16$ & $0.91 \pm 0.11$ \\
Soil moisture (\%) & $3.58 \pm 0.51$ & $5.88 \pm 0.74$ & $8.04 \pm 0.67$ \\
Water holding capacity (\%) & $41.48 \pm 2.19$ & $39.99 \pm 0.43$ & $37.02 \pm 1.03$ \\
Organic carbon (\%) & $1.55 \pm 0.06$ & $1.47 \pm 0.08$ & $1.32 \pm 0.09$ \\
Organic matter (\%) & $2.67 \pm 0.10$ & $2.52 \pm 0.14$ & $2.27 \pm 0.15$ \\
Alkalinity $(\mathrm{mg} / \mathrm{l})$ & $68.66 \pm 0.60$ & $71.15 \pm 0.65$ & $79.52 \pm 1.67$ \\
Sulfate $(\mathrm{mg} / \mathrm{kg})$ & $31.78 \pm 0.55$ & $35.17 \pm 0.25$ & $19.68 \pm 0.32$ \\
Nitrate $(\mathrm{mg} / \mathrm{kg})$ & $24.16 \pm 0.25$ & $26.91 \pm 1.20$ & $32.71 \pm 0.59$ \\
Nitrite $(\mathrm{mg} / \mathrm{kg})$ & $1.29 \pm 0.14$ & $1.58 \pm 0.09$ & $1.48 \pm 0.32$ \\
Available phosphorus $(\mathrm{mg} / \mathrm{kg})$ & $1.82 \pm 0.09$ & $1.51 \pm 0.08$ & $1.89 \pm 0.05$ \\
Potassium $(\mathrm{mg} / \mathrm{kg})$ & $58.65 \pm 0.58$ & $79.91 \pm 0.52$ & $44.03 \pm 0.57$ \\
\hline
\end{tabular}

that dumping sites had significantly higher $\mathrm{pH}$ and organic matter as compared to the control soil.

The alkalinity was found highest at site 3 as compared to other sites and ranged from $68.66 \pm 0.60 \mathrm{mg} / \mathrm{l}$ at site $1,71.15 \pm 0.65 \mathrm{mg} / \mathrm{l}$ at site 2 , and $79.52 \pm 1.67 \mathrm{mg} / \mathrm{l}$ at site 3 , respectively. The high alkalinity indicated the age of the dumping site, association of higher $\mathrm{pH}$ and availability of nutrients in the soil $[1,4]$. The soils of e-waste dumping sites have been reported to be alkaline, with increased $\mathrm{pH}[6,19]$. The sulfate content was significantly varied and found highest at site 2 followed by site 1 and site 3 , respectively. The concentration of nitrate did not vary significantly and found higher at site 3 as compared to site 1 and site 2 . Similarly, the nitrite content was found more at site 2 followed by site 3 and site 1, respectively. Available phosphorus in the contaminated soil sample significantly varied $1.82 \pm 0.09 \mathrm{mg} / \mathrm{kg}$ at site $1,1.51 \pm 0.08 \mathrm{mg} / \mathrm{kg}$ at site 2 , and $1.89 \pm 0.05 \mathrm{mg} / \mathrm{kg}$ at site 3 . The blazing of e-waste might affect the presence of phosphorus in soil and some quantity of phosphorous may have been lost to the air by volatilization [12]. Similar trend of phosphorus content was reported by Liu et al. [35] at e-waste recycling sites in Guiyu town, China. The potassium was found to be higher at site 2 followed by site 1 and site 3. The availability of potassium was influenced by the favorable soil environment and organic matter [44].

A two-tailed test of significance level of $P<0.05$ was used to analyze the correlation coefficient among the various physicochemical characteristics of the soil samples (Table 3). The EC was positively correlated with sulfate and potassium. Organic carbon showed a highly positive correlation with organic matter. Alkalinity and sulfate positively correlated with nitrate and potassium, respectively. However, pH showed marginally optimistic correlation with alkalinity and nitrate and sulfate also exhibited a positive correlation with organic carbon and organic matter to a slight extent.
Table 3 Pearson correlation coefficient $(r)$ among the physicochemical properties of soil samples

\begin{tabular}{|c|c|c|c|c|c|c|c|c|c|c|}
\hline & $\mathrm{pH}$ & $\mathrm{EC}$ & OC & OM & Alkalinity & Sulfate & Nitrate & Nitrite & $\mathrm{K}$ & $P$ \\
\hline $\mathrm{pH}$ & 1 & & & & & & & & & \\
\hline EC & -0.401 & 1 & & & & & & & & \\
\hline OC & $-0.556^{*}$ & 0.450 & 1 & & & & & & & \\
\hline $\mathrm{OM}$ & $-0.559^{*}$ & 0.445 & $0.999 *$ & 1 & & & & & & \\
\hline Alkalinity & $0.733^{*}$ & $-0.655^{*}$ & $-0.765^{*}$ & $-0.765^{*}$ & 1 & & & & & \\
\hline Sulfate & $-0.613^{*}$ & $0.918^{*}$ & $0.682^{*}$ & $0.679 *$ & $-0.891^{*}$ & 1 & & & & \\
\hline Nitrate & $0.727^{*}$ & $-0.585^{*}$ & $-0.735^{*}$ & $-0.735^{*}$ & $0.952^{*}$ & $-0.842^{*}$ & 1 & & & \\
\hline Nitrite & 0.503 & 0.231 & -0.240 & -0.245 & 0.22 & 0.024 & 0.200 & 1 & & \\
\hline K & -0.361 & $0.994^{*}$ & 0.445 & 0.440 & $-0.642^{*}$ & $0.911^{*}$ & $-0.57^{*}$ & 0.249 & 1 & \\
\hline$P$ & 0.21 & $-0.890^{*}$ & -0.115 & -0.109 & 0.416 & $-0.708^{*}$ & 0.359 & -0.279 & $-0.888^{*}$ & 1 \\
\hline
\end{tabular}




\subsection{Characterization of heavy metals}

Heavy metal contents in the study sites were found higher than the USEPA and European soil screening standards. The predominant toxic contaminants in the soil of dumping sites were zinc, iron, manganese, copper, cadmium, chromium lead, and nickel ranging between $110-126 \mathrm{mg} /$ $\mathrm{kg}, 11-18 \mathrm{mg} / \mathrm{kg}, 5-25 \mathrm{mg} / \mathrm{kg}, 148-158 \mathrm{mg} / \mathrm{kg}, 12-17 \mathrm{mg} /$ $\mathrm{kg}, 109-200 \mathrm{mg} / \mathrm{kg}, 61-70 \mathrm{mg} / \mathrm{kg}$, and $11-18 \mathrm{mg} / \mathrm{kg}$, respectively (Fig. 2). The order of occurrence of heavy metals in the contaminated soil was $\mathrm{Cr}>\mathrm{Cu}>\mathrm{Zn}>\mathrm{Pb}>\mathrm{Fe}>\mathrm{M}$ $\mathrm{n}>\mathrm{Cd}>\mathrm{Ni}$. The reference values were: $95 \mathrm{mg} / \mathrm{kg}$ for $\mathrm{Zn}$, $0.7 \mathrm{mg} / \mathrm{kg}$ for $\mathrm{Cd}, 36 \mathrm{mg} / \mathrm{kg}$ for $\mathrm{Cr}, 28 \mathrm{mg} / \mathrm{kg}$ for $\mathrm{Cu}, 31 \mathrm{mg} /$ $\mathrm{kg}$ for $\mathrm{Ni}$, and $28 \mathrm{mg} / \mathrm{kg}$ for $\mathrm{Pb}$ [42].

The findings revealed that electronic waste dumping sites were extremely polluted from the high concentration of copper, cadmium, zinc, lead, and chromium, whereas iron, manganese, and nickel were relatively detected with moderate concentrations. The variations among the heavy metal concentrations probably showed the metal's vertical transference capabilities, as heavy metals mainly preferred to transfer from surface soils to subsoils [51]. Different recycling activities including plastic melting, recovery of copper from the wires, burning of circuits, and using acidic substances to recover gold and other metals may cause the metal pollution at the e-waste sites [30]. Heavy metal pollution at e-waste dumping sites generally found due to the use of many metals in the production of electronic products, e.g., lead and cadmium in circuit boards, copper in electrical wiring, cadmium in computer batteries [21, $58,60,75,80,81]$.

The elevated concentration of $\mathrm{Cd}$ was recorded at selected dumping sites due to the disposal of $\mathrm{NiCd}$ or NiCad rechargeable batteries, which are generally manufactured by nickel oxide hydroxide and metallic cadmium. The high fraction of $\mathrm{Mn}$ was found because of the indefinite leaching of hydrous oxides of manganese at the selected sites [59]. Lead was detected exceptionally high concentration due to the discarding of lead-acid batteries as lead is mainly used in the manufacturing of batteries and assembling of other electronic equipments [15]. An earlier research on heavy metal pollution has identified copper, lead, chromium, and manganese as the major contaminants at three e-waste dumping sites in Nigeria [3]. Tang et al. [64] also reported that chromium, zinc, and lead are the most abundant heavy metals in e-waste recycling city in China. Ha et al. [16] performed a study in Bangalore city and recorded very high concentration of different heavy metals at e-waste recycling unit at slum area (Cr 73 mg/kg, Cu 592 mg/kg, Zn 326 mg/kg, Cd 2.33 mg/ $\mathrm{kg}, \mathrm{Hg} 1.8 \mathrm{mg} / \mathrm{kg}, \mathrm{Pb} 29 \mathrm{mg} / \mathrm{kg}$ ), and concentration in city recycling unit (Cr $57 \mathrm{mg} / \mathrm{kg}$, Cu $22.8 \mathrm{mg} / \mathrm{kg}, \mathrm{Zn} 41 \mathrm{mg} / \mathrm{kg}$, $\mathrm{Cd} 0.165 \mathrm{mg} / \mathrm{kg}, \mathrm{Hg} 0.05 \mathrm{mg} / \mathrm{kg}, \mathrm{Pb} 22.8 \mathrm{mg} / \mathrm{kg}$ ).

Brigden et al. [7] have reported high concentrations of heavy metals in the soil of e-waste handling areas in Delhi, India [56]. Brandl et al. [6] also performed a research study at e-waste contaminated site for heavy metals and recorded very high concentration of these metals, (Al 237 g/kg, Cu 80 g/kg, Pb 20 g/kg, Ni 15 g/kg, Sn 23 g/kg, $\mathrm{Zn} 26 \mathrm{~g} / \mathrm{kg}$ ). Singh et al. [56] also supported the current findings, as they recorded a high concentration of different heavy metals ( $\mathrm{As}, \mathrm{Ba}, \mathrm{Cd}, \mathrm{Cr}, \mathrm{Fe}, \mathrm{Cu}, \mathrm{Mn}, \mathrm{Ni}, \mathrm{Co}$ ) at e-waste recycling sites of Chandigarh and Ludhiana, Punjab, India.

Luo et al. [39] have reported a study at Guangdong province of South China and recorded very high contamination level of various heavy metals $(\mathrm{Cd} 17.1 \mathrm{mg} / \mathrm{kg}, \mathrm{Cr}$ $68.9 \mathrm{mg} / \mathrm{kg}$, Cu 11,140 mg/kg, Ni 60.1 mg/kg, Pb $4500 \mathrm{mg} /$ $\mathrm{kg}$, and Zn $3690 \mathrm{mg} / \mathrm{kg}$ ). The comparison of current findings with earlier research studies is presented in Table 4. The severity of contamination not only depends on the

\section{Heavy Metals Concentration}

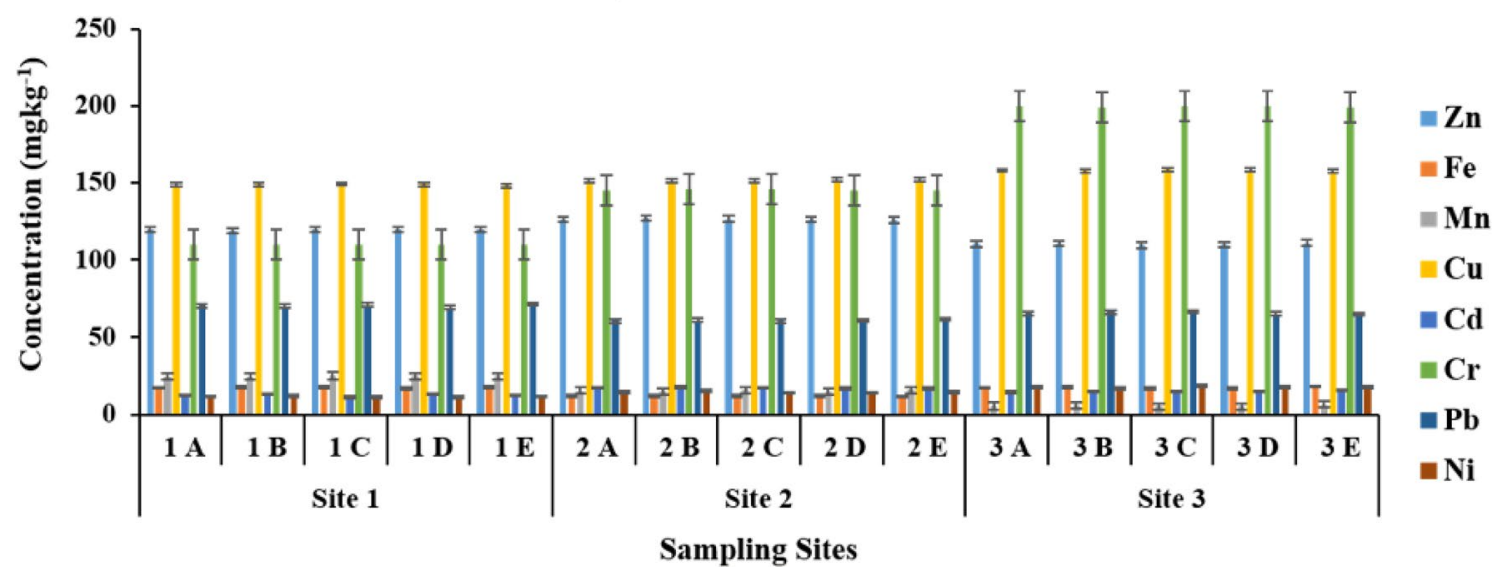

Fig. 2 Concentration $\left(\mathrm{mg} \mathrm{kg}^{-1}\right)$ of heavy metals at different sampling points 
Table 4 Comparison of present results with earlier reports

\begin{tabular}{|c|c|c|c|c|c|c|c|c|c|}
\hline \multirow[t]{2}{*}{ Sites } & \multicolumn{9}{|c|}{ Heavy metals concentrations $(\mathrm{mg} / \mathrm{kg})$} \\
\hline & $\mathrm{Zn}$ & $\mathrm{Fe}$ & $\mathrm{Mn}$ & $\mathrm{Cu}$ & $\mathrm{Cd}$ & $\mathrm{Cr}$ & $\mathrm{Pb}$ & $\mathrm{Ni}$ & Sources \\
\hline e-waste dismantling Sites & $110-126$ & $11-18$ & $5-25$ & $148-158$ & $12-17$ & $109-200$ & $61-70$ & $11-18$ & Current study \\
\hline Site of e-waste dismantling & 258 & - & - & 496 & 1.7 & 28.6 & 104 & 155 & {$[28]$} \\
\hline Dust inside PCB processing & 4420 & - & - & 8360 & - & - & 110,000 & 1500 & {$[27]$} \\
\hline Open-burning site & 2922 & - & - & 7814 & 24.2 & 307 & 3947 & 403.6 & [71] \\
\hline $\begin{array}{l}\text { Qingyuan soil, site of e-waste } \\
\text { dismantling }\end{array}$ & 1016.7 & - & - & 4850.6 & 10.3 & 63.3 & 1714.5 & 100.3 & {$[40]$} \\
\hline Site of e-waste dismantling & 343.2 & - & - & 180.7 & 3.0 & 101.3 & 187.3 & 49 & {$[64]$} \\
\hline Site of e-waste dismantling & 4737.74 & - & - & $14,534.4$ & 8.34 & 287.19 & 1615.8 & 130.24 & {$[56]$} \\
\hline
\end{tabular}

total concentration of metal, but also on the fraction of their movable and bioavailable forms, which generally controlled by the $\mathrm{pH}$, organic matter, and other soil properties [63].

Similarly, a two-tailed test of significance level of $P<0.05$ was used to analyze the correlation coefficient among the various heavy metals. A significant positive correlation was found between some pairs of heavy metals (Table 5). The correlation analysis revealed that copper showed a positive correlation with chromium and nickel, and chromium also positively correlated with nickel. A positive correlation was also observed between iron and lead. The correlation analysis clearly specified that the origination of different heavy metals is possibly electronic waste.

\subsection{Principal component analysis (PCA)}

Multivariate techniques such as principal component analysis can provide an easy mode of discussing the correlated data sets [73] and clarifying the relations between the specific variables and various controlling features by classifying associations among the particular parameters $[33,69]$. PCA used an orthogonal transformation to change a set of observations of possibly correlated multiple variables (different sites and parameters of contaminated soil) into a set of values of linearly uncorrelated variables called principal components.
Principal component analysis of contaminated sites showed a total variability of $59.58 \%$ (Eigenvalue 11.91) for PC 1 and 28.58\% (Eigenvalue 5.70) for PC 2, respectively (Fig. 3). Site 1 showed a negative relation at $P C 1$ and $P C 2$, whereas sites 2 showed positive relation at PC 2 and negative relation at $P C 1$. Site 3 showed a negative relation at PC 2 and positive relation at PC 1. Bi-plot factors analysis of different parameters of selected contaminated sites was varied from 0.05 to 0.27 coefficients variances at PC1.

PC score values for $\mathrm{pH}$, soil moisture, alkalinity, nitrate, nitrite, copper, cadmium, chromium, and nickel revealed a positive relation at PC1 and PC2 (Fig. 3). However, PC score values for water holding capacity, organic carbon, organic matter, manganese, and lead were perceived as highly negative at PC1 and PC2. The score values for electrical conductivity, sulfate, zinc, and potassium were found positive at PC2 and negative at PC1. The loading value of phosphorus and iron was observed positive for $\mathrm{PC} 1$ and negative for PC2. A strong relationship was observed among chromium, copper, nickel, and nitrate for PC1 and $\mathrm{PC2}$. Scores for most of the heavy metals $(\mathrm{Cu}, \mathrm{Ni}, \mathrm{Fe}$, and $\mathrm{Cr}$ ) indicated, more loading at site 3 , due to uninhibited dumping of e-waste, whereas the PC score values for $\mathrm{Mn}$ and $\mathrm{Pb}$ indicated additional loading at Site 1. The PC loading values for $\mathrm{Zn}$ and $\mathrm{Cd}$ showed deposition toward site 2 . Hence, very less heavy metal contents were observed at site 2 , thus a separate group was formed by site 2 .
Table 5 Pearson correlation coefficient $(r)$ among the heavy metals

\begin{tabular}{lllllllll}
\hline & $\mathrm{Zn}$ & $\mathrm{Fe}$ & $\mathrm{Mn}$ & $\mathrm{Cu}$ & $\mathrm{Cd}$ & $\mathrm{Cr}$ & $\mathrm{Pb}$ & $\mathrm{Ni}$ \\
\hline $\mathrm{Zn}$ & 1 & & & & & & & \\
$\mathrm{Fe}$ & $-0.801^{*}$ & 1 & & & & & \\
$\mathrm{Mn}$ & $0.578^{*}$ & 0.007 & 1 & & & & \\
$\mathrm{Cu}$ & $-0.745^{*}$ & 0.212 & $-0.970^{*}$ & 1 & & & \\
$\mathrm{Cd}$ & 0.363 & $-0.812^{*}$ & $-0.518^{*}$ & 0.313 & 1 & & \\
$\mathrm{Cr}$ & $-0.661^{*}$ & 0.102 & $-0.993^{*}$ & $0.987^{*}$ & 0.431 & 1 & \\
$\mathrm{~Pb}$ & -0.422 & $0.857^{*}$ & 0.482 & -0.275 & $-0.973^{*}$ & -0.388 & 1 & \\
$\mathrm{Ni}$ & $-0.608^{*}$ & 0.035 & $-0.989^{*}$ & $0.967^{*}$ & 0.487 & $0.986^{*}$ & -0.43 & 1 \\
\hline
\end{tabular}




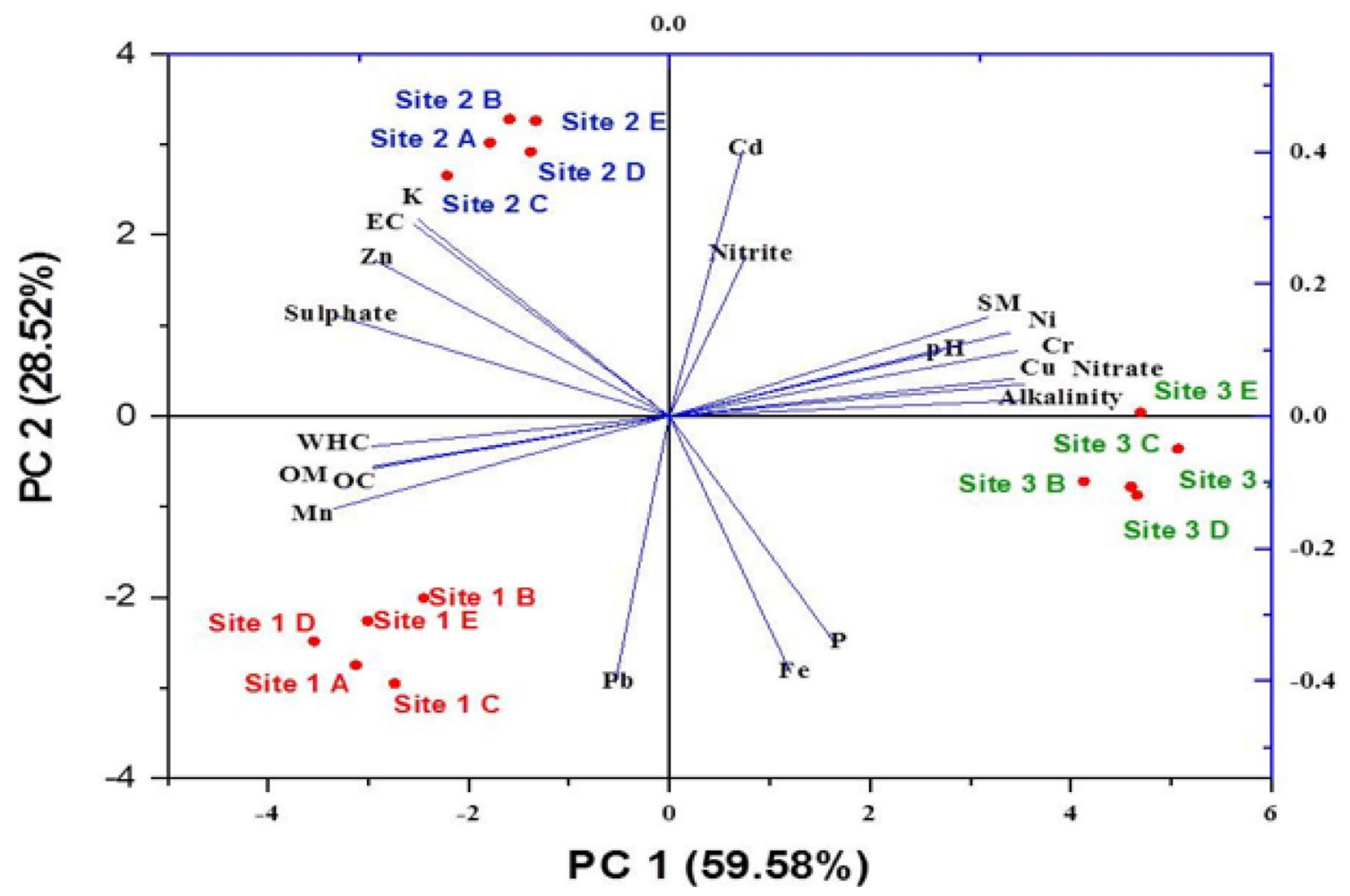

Fig. 3 Principle component analysis (PCA) correlation bi-plot of different physicochemical characteristics of contaminated soil and selected sites. Symbol represents the standardized scores on PC1

\subsection{Cluster analysis}

Cluster analysis, a prevalent approach for determining the multiple-parameter problems [26, 63, 73], was used to determine the spatial similarity matrix among sampling points based on the physicochemical and heavy metals characterization of selected sites. The single linkage method for distance measures was carried out to obtain the clusters, providing much useful information to study the soil contamination. Dendrogram described 14 clusters among the sampling points (Fig. 4).

Sampling point S1A formed four clusters with S1B, S1C, S1D, and S1E with $99.46 \%, 99.33 \%, 99.34 \%$, and $99.55 \%$ of similarity, respectively. Similarly, point S2A also created four clusters with S2B, S2C, S2D, and S2E with $99.56 \%$, $99.67 \%, 99.49 \%$, and $99.36 \%$ of similarity, respectively. Sampling point S3B established two clusters with S2D and S3A with $89.63 \%$ and $99.30 \%$ similarity, respectively. One cluster was formed between S1B and S2E with $93.16 \%$ similarity. Another cluster showed $99.27 \%$ similarity between S2C and S2E. Sampling point S3D created a cluster with S3C with $99.35 \%$ similarity and S3A and S3C formed a cluster with $99.36 \%$ similarity (Table 6).

These clusters indicated that contaminants seem to be associated with the other variables, showing a very high
( $x$-axis) and PC2 (y-axis) for the soil parameters. Vector coordinates represent the correlations between standardized variables and principle components (PCs)

degree of contamination, which suggested that the heavy metals ( $\mathrm{Cu}, \mathrm{Pb}, \mathrm{Ni}, \mathrm{Zn}, \mathrm{Cd}, \mathrm{Cr}, \mathrm{Mn}$, and $\mathrm{Fe}$ ) might have a common source of pollution and influenced by the indiscriminate dumping of e-waste.

\subsection{Assessment of heavy metal contamination}

The heavy metal pollution of the selected dumping sites was assessed by contamination factor $\left(C_{\mathrm{f}}\right)$, degree of contamination $\left(C_{\text {deg }}\right)$, pollution load index (PLI) (Table 7), and geoaccumulation index $\left(I_{\text {geo }}\right)$ (Table 8$)$.

\subsubsection{Contamination factor}

The spatial distribution of CFs for heavy metals ( $\mathrm{Zn}, \mathrm{Cu}$, $\mathrm{Cd}, \mathrm{Cr}$, and $\mathrm{Pb}$ ) in selected e-waste dumping sites is demonstrated in Table 7. The CFs gradient of selected metals established a similar pattern along all the sampling sites. The selected sites (sites 1 , sites 2 , and sites 3 ) were highly contaminated $(\mathrm{Cf} \geq 6)$ with cadmium and moderately contaminated $(1 \leq \mathrm{Cf}<3)$ with Zinc and Lead. In the case of chromium and copper, the sites were considered contaminated as the $\mathrm{CFs}$ were found $(3 \leq \mathrm{Cf}<6)$.

The findings again confirmed that soils of e-waste dumping sites act as a sink for heavy metals and showed 


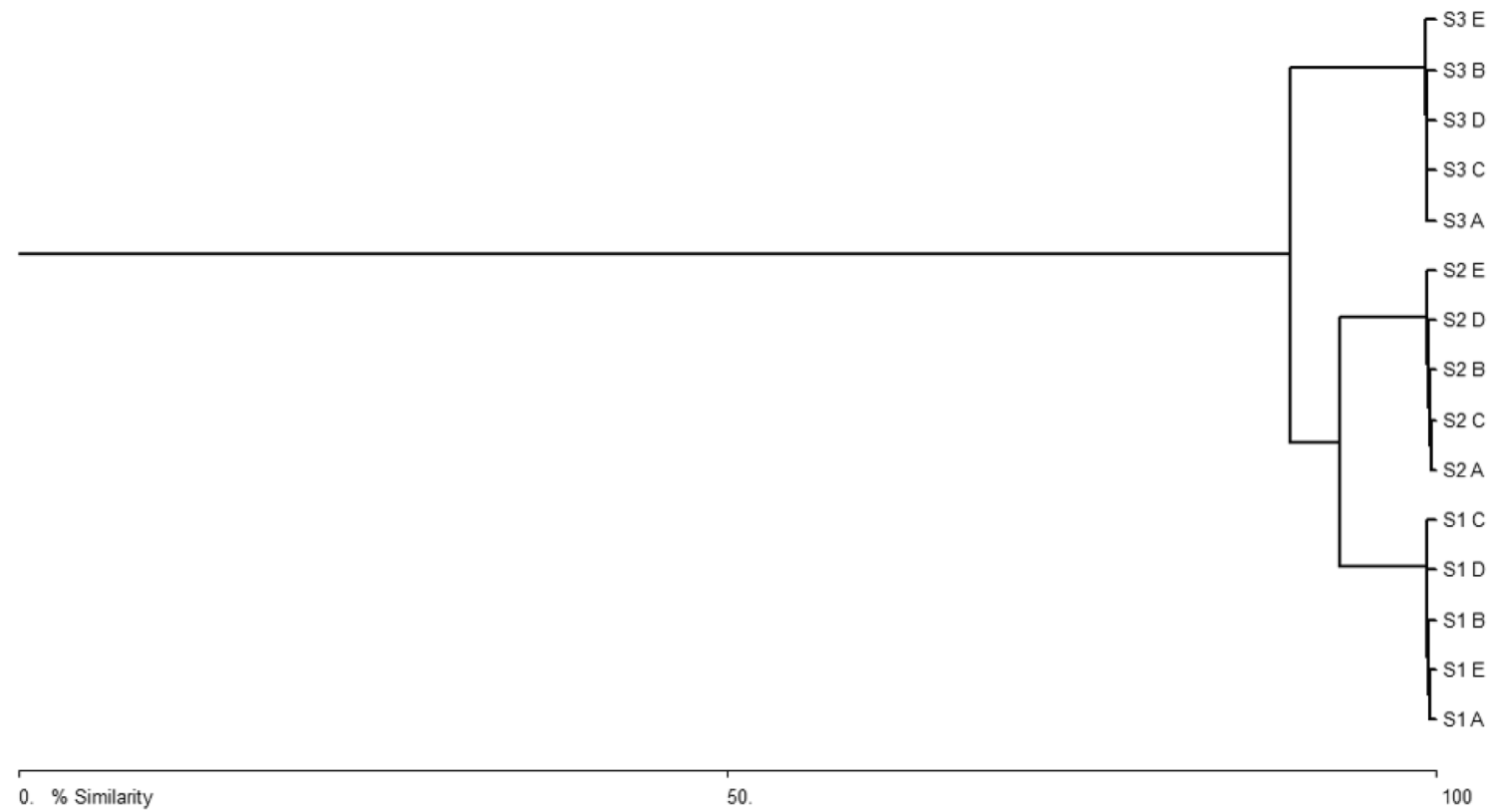

Fig. 4 Dendrogram showing similarity index among all sampling points

Table 6 Similarity matrix among the sampling points

\begin{tabular}{|c|c|c|c|c|c|c|c|c|c|c|c|c|c|c|c|}
\hline & $\mathrm{S} 1 \mathrm{~A}$ & S1 B & $\mathrm{S} 1 \mathrm{C}$ & S1 D & $\mathrm{S} 1 \mathrm{E}$ & $\mathrm{S} 2 \mathrm{~A}$ & S2 B & $\mathrm{S} 2 \mathrm{C}$ & S2 D & $\mathrm{S} 2 \mathrm{E}$ & $\mathrm{S} 3 \mathrm{~A}$ & S3 B & S3 C & S3 D & S3 E \\
\hline S1 A & * & 99.46 & 99.33 & 99.34 & 99.55 & 92.71 & 92.71 & 92.71 & 92.68 & 93.00 & 87.37 & 87.67 & 87.32 & 86.93 & 87.33 \\
\hline S1 B & $*$ & $*$ & 99.05 & 99.26 & 99.40 & 92.87 & 92.89 & 92.83 & 92.82 & 93.16 & 87.74 & 88.07 & 87.69 & 87.28 & 87.72 \\
\hline $\mathrm{S} 1 \mathrm{C}$ & * & * & * & 98.88 & 99.24 & 92.75 & 92.62 & 92.74 & 92.64 & 92.94 & 87.40 & 87.74 & 87.35 & 86.94 & 87.45 \\
\hline S1 D & * & * & * & * & 99.23 & 92.55 & 92.56 & 92.55 & 92.51 & 92.83 & 87.41 & 87.70 & 87.38 & 87.00 & 87.35 \\
\hline S1 E & * & $*$ & * & * & $*$ & 92.65 & 92.66 & 92.64 & 92.62 & 92.94 & 87.41 & 87.73 & 87.37 & 86.95 & 87.39 \\
\hline S2 A & * & * & * & * & * & * & 99.56 & 99.67 & 99.49 & 99.36 & 89.19 & 89.44 & 89.07 & 88.85 & 89.37 \\
\hline S2 B & * & * & * & * & * & * & * & 99.53 & 99.33 & 99.29 & 89.26 & 89.51 & 89.14 & 88.92 & 89.44 \\
\hline $\mathrm{S} 2 \mathrm{C}$ & * & * & * & * & * & * & * & * & 99.43 & 99.27 & 89.21 & 89.47 & 89.09 & 88.87 & 89.39 \\
\hline S2 D & * & * & * & * & * & * & * & * & * & 99.28 & 89.38 & 89.63 & 89.27 & 89.04 & 89.58 \\
\hline S2 E & * & * & * & * & * & * & * & * & * & * & 89.02 & 89.32 & 88.93 & 88.71 & 89.27 \\
\hline S3 A & * & * & * & * & * & * & * & * & $*$ & * & * & 99.30 & 99.36 & 99.33 & 99.22 \\
\hline S3 B & * & * & * & * & * & * & * & * & * & * & * & * & 99.21 & 99.08 & 99.18 \\
\hline S3 C & * & * & * & * & * & * & * & * & * & * & * & * & * & 99.35 & 99.19 \\
\hline S3 D & * & * & * & * & * & * & * & * & * & * & * & * & * & * & 99.27 \\
\hline S3E & * & * & * & * & * & * & * & * & * & * & $*$ & * & $*$ & * & * \\
\hline
\end{tabular}

high contamination from these toxic elements. The sources of contamination at selected dumping sites are (1) haphazard dumping of e-waste, and (2) uncontrolled recycling activities of e-waste in the selected study area.

The degree of contamination for $\mathrm{Zn}, \mathrm{Cu}, \mathrm{Cd}, \mathrm{Cr}$, and $\mathrm{Pb}$ at each sampling point listed in Table 7, which clearly showed that the selected sites were highly contaminated from these metals. At site 2 and site 3 , all the elements contributed to the high degree of contamination $\left(32 \leq C_{\text {deg }}\right)$, whereas a considerable degree of contamination was observed at site $1\left(16 \leq C_{\text {deg }}<32\right)$. Therefore, the findings suggested that all the sampling points at site 2 and 3 showed a high degree of contamination as compared to site 1 .

\subsubsection{Pollution load index (PLI)}

The pollution load index was calculated for every sampling point using the five elements $(\mathrm{Zn}, \mathrm{Cu}, \mathrm{Cd}, \mathrm{Cr}$, and 
Table 7 Contamination factor and pollution load index value

\begin{tabular}{lllllllll}
\hline Sampling sites & $\begin{array}{l}\text { CFs } \\
\text { Zn }\end{array}$ & $\begin{array}{l}\text { CFs } \\
\text { Cu }\end{array}$ & $\begin{array}{l}\text { CFs } \\
\text { Cd }\end{array}$ & $\begin{array}{l}\text { CFs } \\
\text { Cr }\end{array}$ & $\begin{array}{l}\text { CFs } \\
\text { Pb }\end{array}$ & $\begin{array}{l}\text { Contamination } \\
\text { degree }\left(C_{\text {deg }}\right)\end{array}$ & $\begin{array}{l}\text { Pollution } \\
\text { load index }\end{array}$ \\
\hline Site 1 & S1A & 1.26 & 5.31 & 17.37 & 3.05 & 2.52 & 29.51 & 3.89 \\
& S2B & 1.25 & 5.32 & 18.47 & 3.05 & 2.51 & 30.6 & 3.93 \\
& S3C & 1.26 & 5.32 & 15.84 & 3.05 & 2.54 & 28.01 & 3.82 \\
& S4D & 1.26 & 5.31 & 18.59 & 3.06 & 2.48 & 30.7 & 3.93 \\
& S5E & 1.26 & 5.29 & 17.84 & 3.07 & 2.56 & 30.02 & 3.92 \\
& S2A & 1.33 & 5.40 & 25 & 4.03 & 2.2 & 37.96 & 4.36 \\
& S2B & 1.34 & 5.40 & 25.21 & 4.06 & 2.19 & 38.2 & 4.38 \\
& S2C & 1.33 & 5.39 & 24.30 & 4.05 & 2.17 & 37.24 & 4.33 \\
& S2D & 1.33 & 5.43 & 24.27 & 4.04 & 2.17 & 37.24 & 4.33 \\
& S2E & 1.33 & 5.43 & 24.29 & 4.02 & 2.21 & 37.28 & 4.35 \\
& S3A & 1.16 & 5.65 & 20.71 & 5.55 & 2.34 & 35.41 & 4.45 \\
& S3B & 1.16 & 5.64 & 21.51 & 5.52 & 2.37 & 36.2 & 4.49 \\
& S3C & 1.15 & 5.67 & 20.97 & 5.54 & 2.38 & 35.71 & 4.47 \\
& S3D & 1.16 & 5.66 & 21.39 & 5.56 & 2.34 & 36.11 & 4.49 \\
& S3E & 1.17 & 5.63 & 22.70 & 5.52 & 2.32 & 37.34 & 4.53 \\
\hline
\end{tabular}

Table 8 Geoaccumulation index $\left(I_{\text {geo }}\right)$

\begin{tabular}{|c|c|c|c|c|c|c|}
\hline \multicolumn{2}{|c|}{ Sampling sites } & \multirow{2}{*}{$\begin{array}{l}\frac{I_{\text {geo }}}{\mathrm{Zn}} \\
-0.25\end{array}$} & \multirow{2}{*}{$\frac{I_{\text {geo }}}{\mathrm{Cu}}$} & \multirow{2}{*}{$\frac{I_{\text {geo }}}{3.533}$} & \multirow{2}{*}{$\frac{I_{\text {geo }}}{\mathrm{Cr}}$} & \multirow{2}{*}{$\frac{\begin{array}{l}l_{\text {geo }} \\
\mathrm{Pb}\end{array}}{0.748}$} \\
\hline Site 1 & $\mathrm{~S} 1 \mathrm{~A}$ & & & & & \\
\hline & $\mathrm{S} 2 \mathrm{~B}$ & -0.26 & 1.825 & 3.622 & 1.021 & 0.741 \\
\hline & $\mathrm{S} 3 \mathrm{C}$ & -0.24 & 1.83 & 3.40 & 1.025 & 0.758 \\
\hline & S4D & -0.25 & 1.824 & 3.631 & 1.026 & 0.723 \\
\hline & S5E & -0.25 & 1.816 & 3.572 & 1.031 & 0.771 \\
\hline \multirow[t]{5}{*}{ Site 2} & $\mathrm{~S} 2 \mathrm{~A}$ & -0.171 & 1.847 & 4.058 & 1.427 & 0.527 \\
\hline & $\mathrm{S} 2 \mathrm{~B}$ & -0.166 & 1.846 & 4.071 & 1.435 & 0.544 \\
\hline & $\mathrm{S} 2 \mathrm{C}$ & -0.170 & 1.845 & 4.017 & 1.434 & 0.531 \\
\hline & S2D & -0.173 & 1.855 & 4.016 & 1.428 & 0.533 \\
\hline & $\mathrm{S} 2 \mathrm{E}$ & -0.178 & 1.855 & 4.017 & 1.423 & 0.558 \\
\hline \multirow[t]{5}{*}{ Site 3} & $\mathrm{~S} 3 \mathrm{~A}$ & -0.366 & 1.912 & 3.787 & 1.886 & 0.643 \\
\hline & S3B & -0.364 & 1.911 & 3.842 & 1.879 & 0.659 \\
\hline & $\mathrm{S} 3 \mathrm{C}$ & -0.378 & 1.917 & 3.805 & 1.885 & 0.664 \\
\hline & S3D & -0.373 & 1.914 & 3.833 & 1.889 & 0.640 \\
\hline & S3E & -0.359 & 1.908 & 3.919 & 1.88 & 0.632 \\
\hline
\end{tabular}

$\mathrm{Pb}$ ) and presented in Table 7. The average pollution load indices indicated that the sites are highly polluted with heavy metals ( $P L I>1)$. The pattern for highly to least polluted sites was Site $3>$ Site $2>$ Site 1 . The results revealed that all the selected sites suffered from the degradation of soil quality due to heavy metal pollution.

\subsubsection{Geoaccumulation index $\left(I_{\text {geo }}\right)$}

According to the classification suggested by Muller [43], the geoaccumulation index $\left(I_{\text {geo }}\right)$ was used to measure the soil quality of selected e-waste dumping sites at Ahmedabad. Based on $I_{\text {geo }}$ analysis, the selected sites were practically uncontaminated by Zinc, as the $I_{\text {geo }}$ values were found negative. Further, the sites were found uncontaminated to moderately polluted by $\mathrm{Pb}$ as the $I_{\text {geo }}$ values for lead were found between 0 and 1 .

The sampling points at site 1 and site 3 were heavily contaminated by $\mathrm{Cd}$, as the $I_{\text {geo }}$ values were found between 3 and 4 , whereas site 2 was heavily to extremely contaminated by $\mathrm{Cd}$, as the $I_{\text {geo }}$ values were observed more than 4. Copper and chromium showed moderately contamination at all the sampling points, as the obtained values for $I_{\text {geo }}$ were found between 1 and 2 for $\mathrm{Cu}$ and $\mathrm{Cr}$. The results indicated that these metals are the major components of e-waste. 


\section{Conclusion}

The findings of the current research work revealed high concentrations of $\mathrm{Pb}, \mathrm{Zn}, \mathrm{Cd}, \mathrm{Ni}, \mathrm{Cr}, \mathrm{Cu}$, and $\mathrm{Fe}$ in the soil at the e-waste dumping sites, which points to e-waste as a source of heavy metals pollution. The analysis of CFs, PLIs, and $I_{\text {geo }}$ identified these metals as the main pollutants in the soil of the study area. However, further assessment is required to validate the pollutant relation. The current research work highlighted the unregulated dumping of e-waste, which leads to a significant increase in concentrations of heavy metals. The pollution assessment approaches and cluster analysis empowered us to determine the significant contents of heavy metals at an alarming rate at e-waste dumping sites. The levels of heavy metals found in the study area can largely affect human health since the groundwater from the region of e-waste dumping sites is used for human consumption mostly without purification. An extensive assessment needs to be carried out, in the selected region which can establish the e-waste dumping impact on the environment and human health.

Acknowledgements The research work supported by the University Grants Commission, New Delhi, India, under the scheme of Rajiv Gandhi National Fellowship (F1-17.1/2014-15/RGNF-2014-15-SCUTT-69661). The authors are also thankful to the Central University of Gujarat, Gandhinagar for providing Instrumentation Facilities.

\section{Compliance with ethical standards}

Conflict of interest The authors declare that they have no conflict of interest.

\section{References}

1. Adewuyi GO, Opasina MA (2010) Physicochemical and heavy metals assessments of leachates from aperin abandoned dumpsite in Ibadan city, Nigeria. E-J Chem 7(4):1278-1283. https://doi. org/10.1155/2010/401940

2. Akinmosin A, Osinowo O, Oladunjoye M (2009) Radiogenic components of the Nigerian tar sand deposits. Earth Sci Res J 13:64-73

3. Alabi OA, Bakare AA, Xu X, Li B, Zhang Y, Huo X (2012) Comparative evaluation of environmental contamination and DNA damage induced by electronic-waste in Nigeria and China. Sci Total Environ 423:62-72. https://doi.org/10.1016/j.scito tenv.2012.01.056

4. Arias ME, González-pérez JA, González-vila FJ, Ball AS (2005) Soil health-a new challenge for microbiologists and chemists. Int Microbiol 8:13-21

5. Astel A, Astel K, Biziuk M (2008) PCA and multidimensional visualization techniques united to aid in the bioindication of elements from transplanted Sphagnum palustre moss exposed in the Gdańsk City Area. Environ Sci Pollut Res Int 15:41-50. https://doi.org/10.1065/espr2007.05.422

6. Brandl H, Bosshard R, Wegmann M (2001) Computer-munching microbes: metal leaching from electronic scrap by bacteria and fungi. Hydrometallurgy 59(2):319-326. https:// doi.org/10.1016/S0304-386X(00)00188-2

7. Brigden K, Labunska I, Santillo D, Allsopp M (2005) Recycling of electronic wastes in China and India: workplace and environmental contamination. Greenpeace Research Laboratories Technical Note 09/2005, Publ. Greenpeace International, 56

8. Cai L, Xu Z, Ren M, Guo Q, Hu X, Hu G et al (2012) Source identification of eight hazardous heavy metals in agricultural soils of Huizhou, Guangdong Province, China. Ecotoxicol Environ Saf 78:2-8. https://doi.org/10.1016/j.ecoenv.2011.07.004

9. Cataldo DA, Maroon M, Schrader LE, Youngs VL (1975) Rapid colorimetric determination of nitrate in plant tissue by nitration of salicylic acid. Commun Soil Sci Plant Anal 6(1):71-80. https://doi.org/10.1080/00103627509366547

10. Covelo EF, Vega FA, Andrade ML (2007a) Simultaneous sorption and desorption of $\mathrm{Cd}, \mathrm{Cr}, \mathrm{Cu}, \mathrm{Ni}, \mathrm{Pb}$, and $\mathrm{Zn}$ in acid soils I. Selectivity sequences. J Hazard Mater 147(3):852-861. https ://doi.org/10.1016/j.jhazmat.2007.01.123

11. Covelo EF, Vega FA, Andrade ML (2007b) Simultaneous sorption and desorption of $\mathrm{Cd}, \mathrm{Cr}, \mathrm{Cu}, \mathrm{Ni}, \mathrm{Pb}$, and $\mathrm{Zn}$ in acid soils: II. Soil ranking and influence of soil characteristics. J Hazard Mater 147(3):862-870. https://doi.org/10.1016/j.jhazm at.2007.01.108

12. DeBano LF, Klopatek JM (2010) Phosphorus dynamics of pinyonjuniper soils following simulated burning. Soil Sci Soc Am J 52(1):271. https://doi.org/10.2136/sssaj1988.036159950052000 $10048 x$

13. Fox RL, Hue NV, Parra AJ (1987) A turbidimetric method for determining phosphate-extractable sulfates in tropical soils. Commun Soil Sci Plant Anal 18(4):343-357. https://doi. org/10.1080/00103628709367825

14. Fu J, Hu X, Tao X, Yu H, Zhang X (2013) Risk and toxicity assessments of heavy metals in sediments and fishes from the Yangtze River and Taihu Lake, China. Chemosphere 93(9):1887-1895. https://doi.org/10.1016/j.chemosphere.2013.06.061

15. Grant K, Goldizen FC, Sly PD, Brune MN, Neira M, van den Berg M, Norman RE (2013) Health consequences of exposure to e-waste: a systematic review. Lancet Global Health 1(6):e350-e361. https ://doi.org/10.1016/S2214-109X(13)70101-3

16. Ha NN, Agusa T, Ramu K, Tu NPC, Murata S, Bulbule KA et al (2009) Contamination by trace elements at e-waste recycling sites in Bangalore, India. Chemosphere 76(1):9-15. https://doi. org/10.1016/j.chemosphere.2009.02.056

17. Hakanson $L$ (1980) An ecological risk index for aquatic pollution control. A sedimentological approach. Water Res 14(8):9751001. https://doi.org/10.1016/0043-1354(80)90143-8

18. Huang C-L, Bao L-J, Luo P, Wang Z-Y, Li S-M, Zeng EY (2016) Potential health risk for residents around a typical e-waste recycling zone via inhalation of size-fractionated particlebound heavy metals. J Hazard Mater 317:449-456. https://doi. org/10.1016/j.jhazmat.2016.05.081

19. Ilyas S, Anwar MA, Niazi SB, Afzal Ghauri M (2007) Bioleaching of metals from electronic scrap by moderately thermophilic acidophilic bacteria. Hydrometallurgy 88(1-4):180-188. https://doi. org/10.1016/j.hydromet.2007.04.007

20. Udaykumar P, Jose JJ, Krishnan KA, Kumar CSR, Manju MN, Salas PM (2014) Heavy metal accumulation in the surficial sediments along southwest coast of India. Environ Earth Sci. 72(6):18871900. https://doi.org/10.1007/s12665-014-3097-9

21. Jiang B, Adebayo A, Jia J, Xing Y, Deng S, Guo L et al (2019) Impacts of heavy metals and soil properties at a Nigerian e-waste site on soil microbial community. J Hazard Mater 362:187-195. https://doi.org/10.1016/j.jhazmat.2018.08.060

22. Julander A, Lundgren L, Skare L, Grandér M, Palm B, Vahter $M$, Lidén $C$ (2014) Formal recycling of e-waste leads to increased exposure to toxic metals: an occupational exposure study from 
Sweden. Environ Int 73:243-251. https://doi.org/10.1016/j.envin t.2014.07.006

23. Karaca A (2004) Effect of organic wastes on the extractability of cadmium, copper, nickel, and zinc in soil. Geoderma 122(2):297303. https://doi.org/10.1016/j.geoderma.2004.01.016

24. Kovar JL, Pierzynski GM, Hodges SC (2009) Methods of phosphorus analysis for soils, sediments, residuals, and waters-revised edition. Southern Cooperative Series Bulletin. Available: https:// www.sera17.ext.vt.edu/Documents/P_Methods2ndEdition200 9.pdf

25. Kumar P (2018) Electronic waste-hazards, management and available green technologies for remediation-a review. Int Res J Environ Sci 7(5):57-68

26. Kumar P, Kumar R, Reddy MV (2017) Assessment of sewage treatment plant effluent and its impact on the surface water and sediment quality of river Ganga at Kanpur. Int J Sci Eng Res 8(1):1315-1324. https://doi.org/10.14299/ijser.2018.01.003

27. Leung AOW, Duzgoren-Aydin NS, Cheung KC, Wong MH (2008) Heavy metals concentrations of surface dust from e-waste recycling and its human health implications in Southeast China. Environ Sci Technol 42(7):2674-2680. https://doi.org/10.1021/ es071873x

28. Leung Anna, Cai ZW, Wong MH (2006) Environmental contamination from electronic waste recycling at Guiyu, southeast China. J Mater Cycles Waste Manage 8(1):21-33. https://doi. org/10.1007/s10163-005-0141-6

29. Leung AOW, Luksemburg WJ, Wong AS, Wong MH (2007) Spatial distribution of polybrominated diphenyl ethers and polychlorinated dibenzo-p-dioxins and dibenzofurans in soil and combusted residue at Guiyu, an electronic waste recycling site in southeast China. Environ Sci Technol 41(8):2730-2737

30. Li J, Duan H, Shi P (2011) Heavy metal contamination of surface soil in electronic waste dismantling area: site investigation and source-apportionment analysis. Waste Manag Res 29(7):727738. https://doi.org/10.1177/0734242X10397580

31. Li P, Qian H, Howard KWF, Wu J (2015) Heavy metal contamination of Yellow River alluvial sediments, northwest China. Environ Earth Sci 73(7):3403-3415. https://doi.org/10.1007/s1266 5-014-3628-4

32. Li P, Tian R, Liu R (2018) Solute geochemistry and multivariate analysis of water quality in the Guohua phosphorite mine, Guizhou Province, China. Expo and Health. https://doi. org/10.1007/s12403-018-0277-y

33. Li P, Wu J, Qian H (2013) Assessment of groundwater quality for irrigation purposes and identification of hydrogeochemical evolution mechanisms in Pengyang County, China. Environ Earth Sci 69(7):2211-2225. https://doi.org/10.1007/s1266 5-012-2049-5

34. Li P, Wu J, Qian H, Zhou W (2016) Distribution, enrichment and sources of trace metals in the topsoil in the vicinity of a steel wire plant along the Silk Road economic belt, northwest China. Environ Earth Sci 75(10):909. https://doi.org/10.1007/s1266 5-016-5719-x

35. Liu J, He X, Lin X, Chen W, Zhou Q, Shu W, Huang L (2015) Ecological effects of combined pollution associated with e-waste recycling on the composition and diversity of soil microbial communities. Environ Sci Technol 49(11):6438-6447. https:// doi.org/10.1021/es5049804

36. Liu M, Huang B, Bi X, Ren Z, Sheng G, Fu J (2013) Heavy metals and organic compounds contamination in soil from an e-waste region in South China. Environ Sci: Process Impacts 15(5):919-929. https://doi.org/10.1039/C3EM00043E

37. Lou Y, Yang Y, Hu L, Liu H, Xu Q (2015) Exogenous glycinebetaine alleviates the detrimental effect of $\mathrm{Cd}$ stress on perennial ryegrass. Ecotoxicology 24(6):1330-1340. https://doi. org/10.1007/s10646-015-1508-7
38. Lu X, Wang L, Li LY, Lei K, Huang L, Kang D (2010) Multivariate statistical analysis of heavy metals in street dust of Baoji, NW China. J Hazard Mater 173(1):744-749. https://doi. org/10.1016/j.jhazmat.2009.09.001

39. Luo C, Liu C, Wang Y, Liu X, Li F, Zhang G, Li X (2011) Heavy metal contamination in soils and vegetables near an e-waste processing site, south China. J Hazard Mater 186(1):481-490. https://doi.org/10.1016/j.jhazmat.2010.11.024

40. Luo Y, Yu X, Yang Z, Yuan J, Mai B (2008) Studies on heavy metal contamination by improper handling of e-waste and its environmental risk evaluation I. Heavy metal contamination in e-waste open burning sites(in Chinese). Asian J Ecotoxicol 3(1):34-41

41. Mahajan S, Billore D (2014) Assessment of physico-chemical characteristics of the soil of Nagchoon pond Khandwa, MP, India. Res J Chem Sci 4(1):26-30

42. Micó C, Peris M, Recatalá L, Sánchez J (2007) Baseline values for heavy metals in agricultural soils in an European Mediterranean region. Sci Total Environ 378(1):13-17. https://doi.org/10.1016/j. scitotenv.2007.01.010

43. Müller G (1981) The heavy metal pollution of the sediments of neckars and its tributary: a stocktaking. Chemiker Zeitung 105:157-164

44. Nagaraja N, Desai NB, Jayanna HS (2014) A comparative study on the physico-chemical parameters of the soils of Chitradurga District, Karnataka. Indian J Sci Res 5(2):23-28

45. Noel-Brune $M$, Goldizen FC, Neira $M$, van den Berg $M$, Lewis $N$, King $M$ et al (2013) Health effects of exposure to e-waste. Lancet Global Health 1(2):e70. https://doi.org/10.1016/S2214 $-109 \times(13) 70020-2$

46. Osuji LC, Adesiyan SO (2005) The isiokpo oil-pipeline leakage: total organic carbon/organic matter contents of affected soils. Chem Biodivers 2(8):1079-1085. https://doi.org/10.1002/ cbdv.200590077

47. Oyedele D, Gasu MB, Awotoye O (2008) Changes in soil properties and plant uptake of heavy metals on selected municipal solid waste dump sites in Ile-Ife, Nigeria. Afr J Environ Sci Technol 3:107-115

48. Perkins DN, Brune Drisse MN, Nxele T, Sly PD (2014) e-waste: a global hazard. Annals of Global Health 80(4):286-295. https:// doi.org/10.1016/j.aogh.2014.10.001

49. Prasanna MV, Praveena SM, Chidambaram S, Nagarajan R, Elayaraja A (2012) Evaluation of water quality pollution indices for heavy metal contamination monitoring: a case study from Curtin Lake Miri City, East Malaysia. Environ Earth Sci 67(7):19872001. https://doi.org/10.1007/s12665-012-1639-6

50. Quan S-X, Yan B, Yang F, Li N, Xiao X-M, Fu J-M (2015) Spatial distribution of heavy metal contamination in soils near a primitive e-waste recycling site. Environ Sci Pollut Res 22(2):1290-1298. https://doi.org/10.1007/s11356-014-3420-8

51. Raveh-Rubin S, Edery Y, Dror I, Berkowitz B (2015) Nickel migration and retention dynamics in natural soil columns. Water Resour Res 51(9):7702-7722. https://doi.org/10.1002/2015W R016913

52. Robinson BH (2009) E-waste: an assessment of global production and environmental impacts. Sci Total Environ 408(2):183191. https://doi.org/10.1016/j.scitotenv.2009.09.044

53. Salem HM, Eweida EA, Farag A (2000) Heavy metals in drinking water and their environmental impact on human health. Icehm 2000:542-556

54. Sanusi A (2015) Impact of burning e-waste on soil physicochemical properties and soil microorganisms. Br Microbiol Res J 8(2):434-442. https://doi.org/10.9734/bmrj/2015/16874

55. Seshan BRR, Natesan U, Deepthi K (2010) Geochemical and statistical approach for evaluation of heavy metal pollution in core 
sediments in southeast coast of India. Int J Environ Sci Technol 7(2):291-306

56. Singh $M$, Thind PS, John $S$ (2018) Health risk assessment of the workers exposed to the heavy metals in e-waste recycling sites of Chandigarh and Ludhiana, Punjab, India. Chemosphere 203:426-433. https://doi.org/10.1016/j.chemospher e.2018.03.138

57. Singh S, Yadav RH (2019) Heavy metal contamination and pollution indices in roadside soils of Ahmedabad, Gujarat. Int J Sci Res Rev 8(2):1839-1851

58. Song Q, Li J (2015) A review on human health consequences of metals exposure to e-waste in China. Environ Pollut 196:450461. https://doi.org/10.1016/j.envpol.2014.11.004

59. Staelens N, Parkpian P, Polprasert C (2000) Assessment of metal speciation evolution in sewage sludge dewatered in vertical flow reed beds using a sequential extraction scheme. Chem Speciat Bioavailab 12(3):97-107. https://doi.org/10.3184/09542 2900782775517

60. Stevels A, Huisman J, Wang F, Li J, Li B, Duan H (2013) Take back and treatment of discarded electronics: a scientific update. Front Environ Sci Eng 7(4):475-482. https://doi.org/10.1007/s1178 3-013-0538-8

61. Sun D, Bi Q, Li K, Dai P, Yu Y, Zhou W et al (2018) Significance of temperature and water availability for soil phosphorus transformation and microbial community composition as affected by fertilizer sources. Biol Fertil Soils 54(2):229-241. https://doi. org/10.1007/s00374-017-1252-7

62. Suresh G, Sutharsan P, Ramasamy V, Venkatachalapathy R (2012) Assessment of spatial distribution and potential ecological risk of the heavy metals in relation to granulometric contents of Veeranam lake sediments, India. Ecotoxicol Environ Saf 84:117124. https://doi.org/10.1016/j.ecoenv.2012.06.027

63. Tang X, Shen C, Chen L, Xiao X, Wu J, Khan Ml et al (2010) Inorganic and organic pollution in agricultural soil from an emerging e-waste recycling town in Taizhou area. China. Journal of Soils and Sediments 10(5):895-906. https://doi.org/10.1007/ s11368-010-0252-0

64. Tang X, Shen C, Shi D, Cheema SA, Khan MI, Zhang C, Chen Y (2010) Heavy metal and persistent organic compound contamination in soil from Wenling: an emerging e-waste recycling city in Taizhou area, China. J Hazard Mater 173(1):653-660. https:// doi.org/10.1016/j.jhazmat.2009.08.134

65. Tautua A, Bamidele MW, Onigbinde AO, Ere D (2014) Assessment of some heavy metals and physicochemical properties in surface soils of municipal open waste dumpsite in Yenagoa, Nigeria. Afr J Environ Sci Technol 8(1):41-47. https://doi.org/10.5897/ AJEST2013.1621

66. Turekian KK, Wedepohl KH (1961) Distribution of some major elements of the Earth's crust. Geol Soc Am Bull 72:175-192

67. Uba S, Uzairu A, Harrison GFS, Balarabe ML, Okunola OJ (2008) Assessment of heavy metals bioavailability in dumpsites of Zaria Metropolis. Nigeria. Afr J Biotech 7(2):122-130

68. Wagai R, Mayer LM, Kitayama K, Knicker H (2008) Climate and parent material controls on organic matter storage in surface soils: a three-pool, density-separation approach. Geoderma 147(1):23-33. https://doi.org/10.1016/j.geoderma.2008.07.010

69. Wang Y, Jiao JJ (2012) Origin of groundwater salinity and hydrogeochemical processes in the confined Quaternary aquifer of the Pearl River Delta, China. J Hydrol 438-439:112-124. https:// doi.org/10.1016/j.jhydrol.2012.03.008

70. Woermann D (1973) R. G. Bates: determination of $\mathrm{pH}$, Theory and Practice. 2nd Edition, John Wiley \&amp; Sons, New York, London,
Sydney, Toronto 1973. 479 Seiten. Preis: $£$ 10.00. Ber Bunsenges Phys Chem 77(9):737. https://doi.org/10.1002/BBPC.19730 770918

71. Wong CSC, Duzgoren-Aydin NS, Aydin A, Wong MH (2007) Evidence of excessive releases of metals from primitive e-waste processing in Guiyu, China. Environ Pollut 148(1):62-72. https ://doi.org/10.1016/j.envpol.2006.11.006

72. Wong MH, Wu SC, Deng WJ, Yu XZ, Luo Q, Leung AOW et al (2007) Export of toxic chemicals - A review of the case of uncontrolled electronic-waste recycling. Environ Pollut 149(2):131140. https://doi.org/10.1016/j.envpol.2007.01.044

73. Wu J, Li P, Qian H, Duan Z, Zhang X (2014) Using correlation and multivariate statistical analysis to identify hydrogeochemical processes affecting the major ion chemistry of waters: a case study in Laoheba phosphorite mine in Sichuan, China. Arab J Geosci 7(10):3973-3982. https://doi.org/10.1007/s1251 7-013-1057-4

74. Wu J, Li P, Wang D, Ren X, Wei M (2019) Statistical and multivariate statistical techniques to trace the sources and affecting factors of groundwater pollution in a rapidly growing city on the Chinese Loess Plateau. Hum Ecol Risk Assess. https://doi. org/10.1080/10807039.2019.1594156

75. Wu Q, Leung JYS, Geng X, Chen S, Huang X, Li H et al (2015) Heavy metal contamination of soil and water in the vicinity of an abandoned e-waste recycling site: implications for dissemination of heavy metals. Sci Total Environ 506-507:217-225. https ://doi.org/10.1016/j.scitotenv.2014.10.121

76. Yang H, Zhou J, Feng J, Zhai S, Chen W, Liu J, Bian X (2019) Chapter five-ditch-buried straw return: a novel tillage practice combined with tillage rotation and deep ploughing in rice-wheat rotation systems. In: Sparks DL (ed) Advances in agronomy, vol 154. Academic Press, Cambridge, pp 257-290. https://doi. org/10.1016/bs.agron.2018.11.004

77. Yang $Y$, Xue $M, X u Z$, Huang $C(2013)$ Health risk assessment of heavy metals $(\mathrm{Cr}, \mathrm{Ni}, \mathrm{Cu}, \mathrm{Zn}, \mathrm{Cd}, \mathrm{Pb})$ in circumjacent soil of a factory for recycling waste electrical and electronic equipment. J Mater Cycles Waste Manage 15(4):556-563. https://doi. org/10.1007/s10163-013-0120-2

78. Yang Z, Lu W, Long Y, Bao X, Yang Q (2011) Assessment of heavy metals contamination in urban topsoil from Changchun City, China. J Geochem Explor 108(1):27-38. https://doi. org/10.1016/j.gexplo.2010.09.006

79. Yongming H, Peixuan D, Junji C, Posmentier ES (2006) Multivariate analysis of heavy metal contamination in urban dusts of Xi'an, Central China. Sci Total Environ 355(1):176-186. https ://doi.org/10.1016/j.scitotenv.2005.02.026

80. Zeng X, Li J, Singh N (2014) Recycling of spent lithium-ion battery: a critical review. Crit Rev Environ Sci Technol 44(10):11291165. https://doi.org/10.1080/10643389.2013.763578

81. Zhang Q, Ye J, Chen J, Xu H, Wang C, Zhao M (2014) Risk assessment of polychlorinated biphenyls and heavy metals in soils of an abandoned e-waste site in China. Environ Pollut 185:258265. https://doi.org/10.1016/j.envpol.2013.11.003

Publisher's Note Springer Nature remains neutral with regard to jurisdictional claims in published maps and institutional affiliations. 